\title{
SCARCITY AS A DESIRABLE ATTRIBUTE OF LUXURY FASHION BRANDS IN MILLENNIAL MARKETING
}

\section{NESTAŠICA KAO POŽELJNA \\ KARAKTERISTIKA LUKSUZNIH MARKI U MARKETINGU USMJERENOM MILENIJALCIMA}

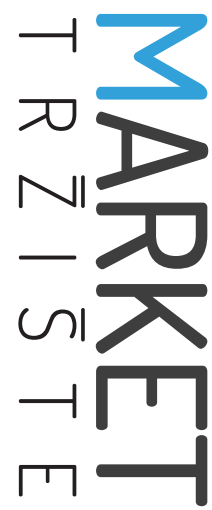

Market-Tržište

Vol. 31, №. 2, 2019, pp. 153-170

UDK 658.89:658.626:316.346.36

DOl http://dx.doi.org/10.22598/mt/2019.31.2.153

Original scientific paper

\author{
Javier F. de la Ballina ${ }^{a}$, Isabel de la Ballinab \\ a University of Oviedo, Avenida del Cristo sn, 33071 Oviedo, SPAIN, e-mail: fballina@uniovi.es \\ b University of Navarra, ISEM Fashion Business School, Calle Marquesado de Sta. Marta 3, 28022 Madrid, SPAIN, e-mail: \\ U0244888@uniovi.es
}

\begin{abstract}
Purpose - Marketing literature considers scarcity a mechanism that increases the desirability of the offer and an inherent attribute of luxury products. This market needs to capture the millennial segment. The objective of this paper is to develop a proper scarcity strategy to be used when connecting luxury brands to millennials.

Design/methodology/approach - An empirical study based on an experimental design was carried out to test the effect of each of the strategies (second line, my luxury, or exclusive selection of cheaper products) on different dimensions of how millennials perceive luxury brands (refinement, elitism, and hedonism), looking for causality relationships.
\end{abstract}

Findings - The hedonism factor, closely connected with purchase experience, seems to be the most valuable for millennials and best encouraged by the second line strategy. In this way, luxury brands draw millennials into their market in a natural way, through an accessible price. But the second line strategy could imply a process of brand devaluation for the traditional customer base.

Limitations - The difference in the results obtained using the "current shopping intention" and "future shopping intention" variables deserves more attention.

\section{Sažetak}

Svrha - Marketinška literatura razmatra nestašicu kao mehanizam koji povećava poželjnost ponude i svojstveni atribut luksuznih proizvoda. To tržište treba dosegnuti segment milenijalaca. Cilj je rada razviti odgovarajuću strategiju nestašice za povezivanje luksuznih marki s milenijalcima.

Metodološki pristup - Provedeno je empirijsko istraživanje temeljeno na eksperimentalnom dizajnu kako bi se ispitao utjecaj svake strategije (druga linija, moj luksuz ili ekskluzivni izbor jeftinijih proizvoda) na različite dimenzije načina na koje milenijalci percipiraju luksuzne marke (profinjenost, elitizam i hedonizam), u potrazi za uzročno-posljedičnim odnosima.

Rezultati i implikacije - Čini se da je čimbenik hedonizma, usko povezan s iskustvom kupovine, najvrjedniji za milenijalce i najbolje ga podupire strategija druge linije. Na ovaj način luksuzne marke privlače milenijalce na svoje tržište prirodnim putem po pristupačnoj cijeni. No, strategija druge linije bi mogla implicirati proces devaluacije marke (pripisivanja negativnih značajki marki) za tradicionalnu bazu potrošača.

Ograničenja - Razlika u rezultatima dobivenim varijablama "trenutna namjera kupovine" i "namjera buduće 
Different ways of measuring future shopping intention could be applied to test the effects on the results.

Originality/value - A different methodology, that is, an experimental study is presented to compare marketing strategies in the luxury market. In this way, a better relationship between exclusivity and the needs of millennials can be established as regards their attraction to luxury brands.

Keywords - marketing, scarcity, luxury, millennials, experimental design kupovine" zaslužuje više pozornosti. Primijeniti se mogu različiti načini mjerenja namjere buduće kupovine kako bi se istražili učinci na rezultate.

Doprinos - Korištena je drugačija metodologija, eksperimentalni dizajn, za usporedbu marketinških strategija na tržištu luksuznih proizvoda. Na ovaj se način može uspostaviti bolji odnos između ekskluzivnosti i potreba milenijalaca zbog njihova privlačenja luksuznim markama.

Ključne riječi - marketing, nestašica, luksuz, milenijalci, eksperimentalni dizajn 


\section{INTRODUCTION}

Scarcity has been used as a marketing technique for many years. Evidence shows that limited supply can induce arousal and, therefore, positively influence attractiveness (Zhu \& Ratner, 2015). Grossman and Mendoza (2003) pointed out that, as a resource becomes scarce, people's willingness to compete with others for that limited resource increases and, consequently, the attention directed towards it becomes greater. The importance of scarcity as a signal of perceived value results from the fact that purchasing decisions are not taken after deep thought but are more impulsive. "Buy it now or regret forever", is the underlying motto that explains, for example, phenomena as relevant as fast fashion (Aguirre, 2013).

The work of the 2002 Nobel laureate Daniel Kahneman (Kahneman, Rosenfield, Gandhi \& Blaser, 2016), Robert Shiller (Nobel awarded, 2013) (Shiller, 2015), or the latest Nobel laureate Richard Thaler (Tahler \& Ganser, 2015) shows the importance of irrational decision-making behavior on economy. The consumer response to scarce items may be found in that sphere of irrational choice (Chiu \& Peng, 2018).

Previous literature has dealt with changes in consumer behavior from a more cautious to a more emotional way. Cialdini (2009, p. 267) suggests that "when something that people like is less available, consumers become physically agitated, such that their focus narrows, emotion rises, and cognitive processes are often suppressed by 'brain-clouding arousal'". Another line of research indicates that it is the transition from a historically abundant supply psychology (mass production) to a scarce mind-set that causes arousal (Berlyne, 1969), as consumers have to "face input changes to which they were not accustomed, especially if input is scarce, surprising, and novel" (Pribram \& McGuinness, 1975).

Research in the field of scarcity has demonstrated that scarce items help consumers to order their preferences (Cassidy, 2018). Scarcity does not boost attractiveness to the same level but rather polarizes evaluative judgments. It makes judgments of positive items more positive and judgments of negative items more negative (Arminen, 2017).

The managing of scarcity is particularly relevant in the luxury industry. Scarcity and exclusivity are intimately related (Oruc, 2015). Reaching the millennial target is top of the agenda for marketing professionals of the luxury industry nowadays (Giovannini, Xu \& Thomas, 2015). The objective of this paper is to develop a proper scarcity strategy when connecting luxury brands to millennials. In order to attain this goal, the first section of this research deals with the concept of scarcity and the factors that influence it. The second section describes the luxury fashion market and its most recent evolution. The millennials' shopping behavior and their connection with luxury fashion brands is described in section three. The empirical study based on an experimental design is presented in section four. Finally, this study concludes with a summary of the most relevant results as well as a description of the main managerial implications, limitations, and future research directions.

\section{SCARCITY IN THE LUXURY FASHION MARKETING}

Marketers have been deeply curious about the influence of scarcity. Scarcity can sway the choice of consumers among a particular assortment (Mair, 2018). Good scarcity management can be a source of competitive advantage ( $\mathrm{Gi}$ erl, Plantsch \& Schweidler, 2008). There are at least two types of scarcity: that which is due to a quantity limitation and that which is due to a time limitation (see Figure 1). In the case of a quantity limitation, the degree of scarcity varies with each unit sold, so both supply and demand factors can be influenced (Aggarwal, Jun \& Huh, 2011). Limitations in the quantity offered are commonly used by sellers as a marketing tool to publicly limit the availability of a product. The main example is the ever-popular "limited edi-

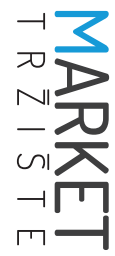


tion", in which only a certain number of goods is produced and no further production is carried out (Balachander \& Stock, 2009). On the other hand, demand factors arise naturally during the selling process. The seller communicates in real time the stock left of the product to prove its unavailability. This is the case of online messages commonly posted on web sites such as, "only 2 units left" (Gierl et al., 2008).

With scarcity due to a time limitation, the degree of unavailability increases as time goes by, and it is only the vendor who can influence it by setting a more restrictive or more open border of availability (Brannon \& Brock, 2001). An important distinction is whether the product is conspicuous or non-conspicuous (see Figure 2). Conspicuous products are characterized by the function they display on satisfying social needs of their owners (Wang \& Griskevicius, 2013). This is the case which jewelry, clothing, or automobiles. All these products help their owners communicate something about themselves to other people.

FIGURE 1: Types of scarcity

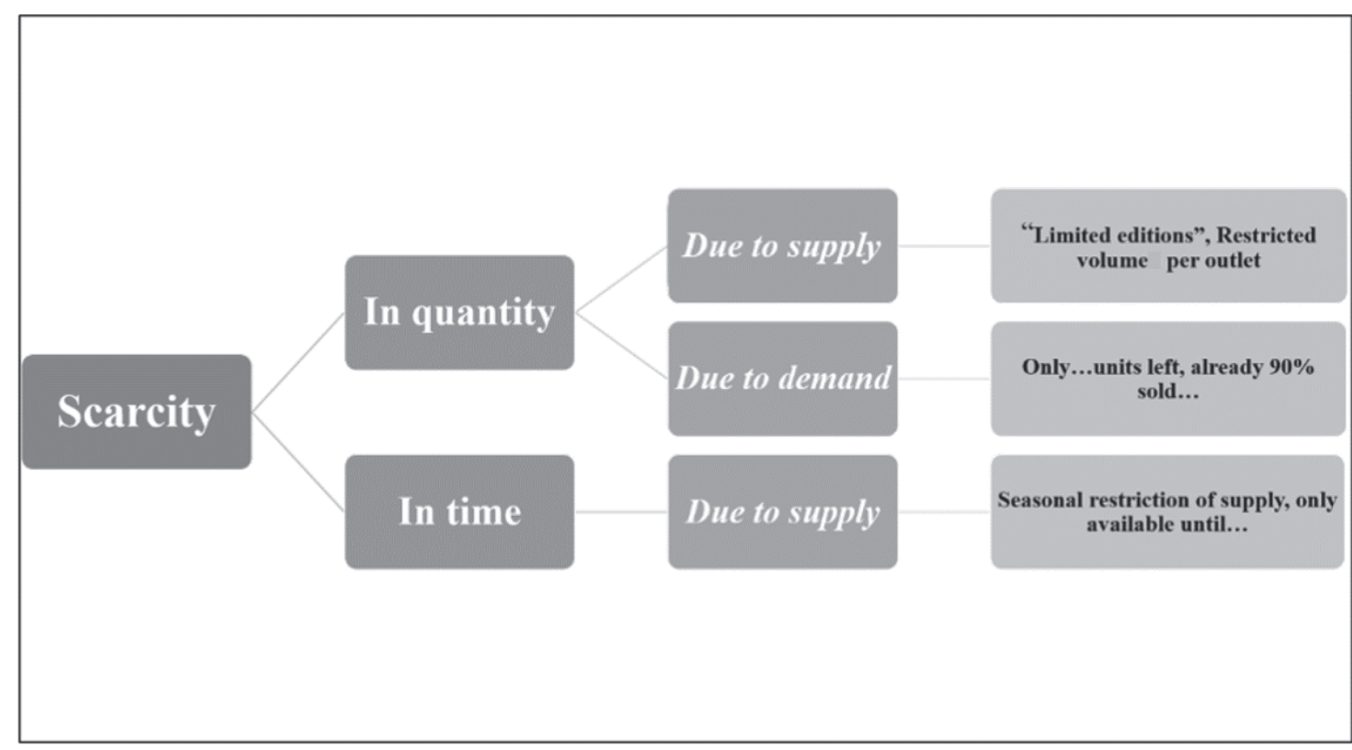

Source: Adapted from Gierl et al. (2008)

FIGURE 2: Effect of scarcity on conspicuous and non-conspicuous products

\begin{tabular}{|c|c|c|c|c|}
\hline & \multicolumn{3}{|c|}{ CONSPICUOUS PRODUCTS } & \multirow{2}{*}{$\begin{array}{c}\text { NON- } \\
\text { CONSPICUOUS } \\
\text { PRODUCTS }\end{array}$} \\
\hline & Status Symbol & Uniqueness & Conformity & \\
\hline $\begin{array}{l}\text { SCARCITY DUE TO } \\
\text { SUPPLY }\end{array}$ & positive & positive & positive & no effect \\
\hline $\begin{array}{l}\text { SCARCITY DUE TO } \\
\text { DEMAND }\end{array}$ & negative & negative & positive & positive \\
\hline SCARCITY IN TIME & no effect & no effect & no effect & positive \\
\hline
\end{tabular}

Source: Adapted from Gierl \& Huettl (2010) 
The authors considered three motives for buying conspicuous products (Corneo \& Jeanne, 1997):

a) A status symbol - It usually applies to products, such as jewelry or automobiles, able to signal a high social status (Blumberg, 1974).

b) Uniqueness compared to friends and colleagues - It applies to unusual products that imply some kind of social risk disapproval, but also give the consumers the sense of being innovators or fashion leaders (Tian, Bearden \& Hunter, 2001).

c) Conformity with exclusive social groups - It normally applies to products that are highly appreciated in particular social groups (Lascu \& Zinkan, 1999).

Even when a status symbol, "uniqueness and conformity can be to some extent relevant in the purchase of conspicuous products, the truth is that in most cases one of these motives can be dominant over the others" (Brewer \& Pierce, 2005). Depending on which of the motives is prevalent, companies should try to use a different scarcity strategy. Thus, in the case of status and uniqueness, the desire of the consumer is to signal high status and enhance his/her uniqueness and exclusivity. Consequently, the application of a scarcity strategy based on limited supply seems reasonable (Amaldoss \& Jain, 2005; Lynn \& Harris, 1997; Worchel, 1992). Alternatively, both supply and demand scarcity strategies can be valuable in the case of conformity.

In the purchase of non-conspicuous products, the main driving factors are the intrinsic attributes or benefits (Okada, 2005). Purchasing decisions of non-conspicuous products are based not only on purchase arguments but also on heuristic information (Eagly \& Chaiken, 1993). The notion that "so many buyers can't be wrong" leads to a greater desirability for highly demanded products. Consequently, when it comes to non-conspicuous products, quantitative unavailability due to excess of demand seems to be more influential. In addition, Whittler (1994) demonstrated that scarcity in time could also lead to positive effects, as consumers tend to buy scarce products because they fear a possible increase in the price level or out-ofstock conditions.

While nowadays consumers are more conscious of the techniques of persuasion employed by marketers, tactics related with product scarcity are still very effective. This is especially true when new products are launched (Stock \& Balachander, 2005), when applying price promotions (Suri, Kohli \& Monroe, 2007), or when limited editions are announced (Lystig \& Johnson, 2003). The fact that scarcity and exclusivity are correlated (Radón, 2012) is of utmost importance in the luxury fashion market. Dubois, Laurent and Czellar (2001) considered the concept and attributes of luxury brands and agreed with other authors that exclusivity is the main purchase driver of luxury products (Figure 3).

\section{FIGURE 3: Characteristics of luxury products}

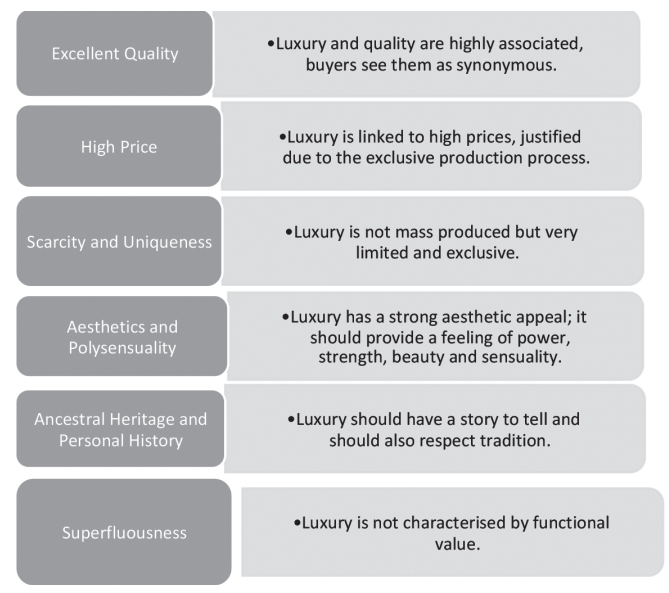

Source: Adapted from Dubois et al. (2001)

Luxury is commonly unchangeable but fashion changes constantly. Therefore, a balance should be achieved to maintain the illusion of exclusivity while, at the same time, keeping up with trends in order not to become obsolete (Fionda \& Moore, 2009). This question is related to the three-level classification of luxury brands that has been proposed (D'Arpizio, Levatno, Zito, Kamel \& de Montgolfier, 2016): absolute luxury 
brands, aspirational luxury brands, or accessible luxury brands. The concept of "my luxury" arises as a factor of cohesion between these levels. It refers to the purchase of small personal luxury products, rather than more expensive ones (Kapferer, 2012). The "lipstick effect" is a clear exponent of this trend.

A "new luxury" has recently flourished. It is represented by products that, while still possessing high levels of quality, taste, and aspiration, are more accessible to the middle market. Contemporary consumers use consumption to make statements about themselves, to create identities, and to develop a sense of belonging (Danziger, 2005). It is a "luxurification of society" (Atwal \& Williams, 2009).

\section{MILLENNIALS AND LUXURY FASHION}

Strategies related with managing scarcity to increase the sense of exclusiveness have been successful with traditional generations. However, the millennial generation is characterized by a strong adoption of the new concept of luxury fashion, no longer related with possessing but with experiencing. Luxury fashion has moved from its "old conspicuous consumption" model to a new one adapted to new needs and desires for experiences (Ko, Phau \& Aiello, 2016). An essential component of a brand's strategy nowadays is delivering emotional value throughout the purchasing experience (Catry, 2013).

Millennials use different social media platforms, so their engagement with brands and companies is deeper and more relevant (Baron, 2015; Barton, Fromm \& Egan, 2012a; Boston Consulting Group, 2015). They are both users and consumers of digital media, they seek out brands directly. They manifest their preferences in real time, so they make a permanent promotion of what they do or do not like (Moreno, La Fuente, Carreón \& Moreno, 2017). The transition from a unilateral to a bilateral communication practice has clearly empowered them (Ellwood \& Shekar, 2008; Yarrrow \& O'Donnell, 2009). However, millennials tend to show low brand loyalty (Giovannini et al., 2015; Jay, 2012; Moreno et al., 2017; Parment, 2012). They try to find brands that better match their values, personality, beliefs, and lifestyles. Nevertheless, as they are still in stages of growth, their preferences will be altered over the years, generally evolving into low brand ties (Barton, Fromm \& Egan, 2012b; Giovannini et al., 2015). An intrinsic characteristic of this generation is the need for acceptance. This trait explains why they tend to shop in groups and how influential third parties are (Barton et al., 2012a; Giovannini et al., 2015). They place more trust in the reviews of other peers than in regular advertisements (Allsop, Bassett \& Hoskins, 2007; Barton et al., 2012b).

A recent study by Deloitte (2017) shows that millennials have a substantially higher interest in buying luxury products than older generations had (63\% versus $36 \%$ ). This trend is even higher in the case of women (see Figure 4). Valentine and Powers (2013) stated that millennials' main purchases are related with conspicuous products. They can be used as tools for signaling status, wealth and purchasing power (Lissitsa \& Kol, 2016).

Millennials' life philosophy of "living the moment" make them spend money more rapidly than did the previous generation (Moreno et al., 2017). Besides, having an enormous quantity of information available to them, they are an impatient and demanding generation: "I want it all and I want it now" (Barton et al., 2012b). For all these reasons, they are sensitive to scarcity strategies and are not used to facing unavailability. The fear of not getting "what they want and when they want it" induces them to buy on impulse (Yarrow \& O'Donnell, 2009).

In what can be considered an unexpected tendency, millennials have largely contributed to the growth of luxury brands (Barton et al., 2012b; Solomon, 2017). The following factors can explain this tendency (Ressel, 2016): 
FIGURE 4: Millennial luxury branding

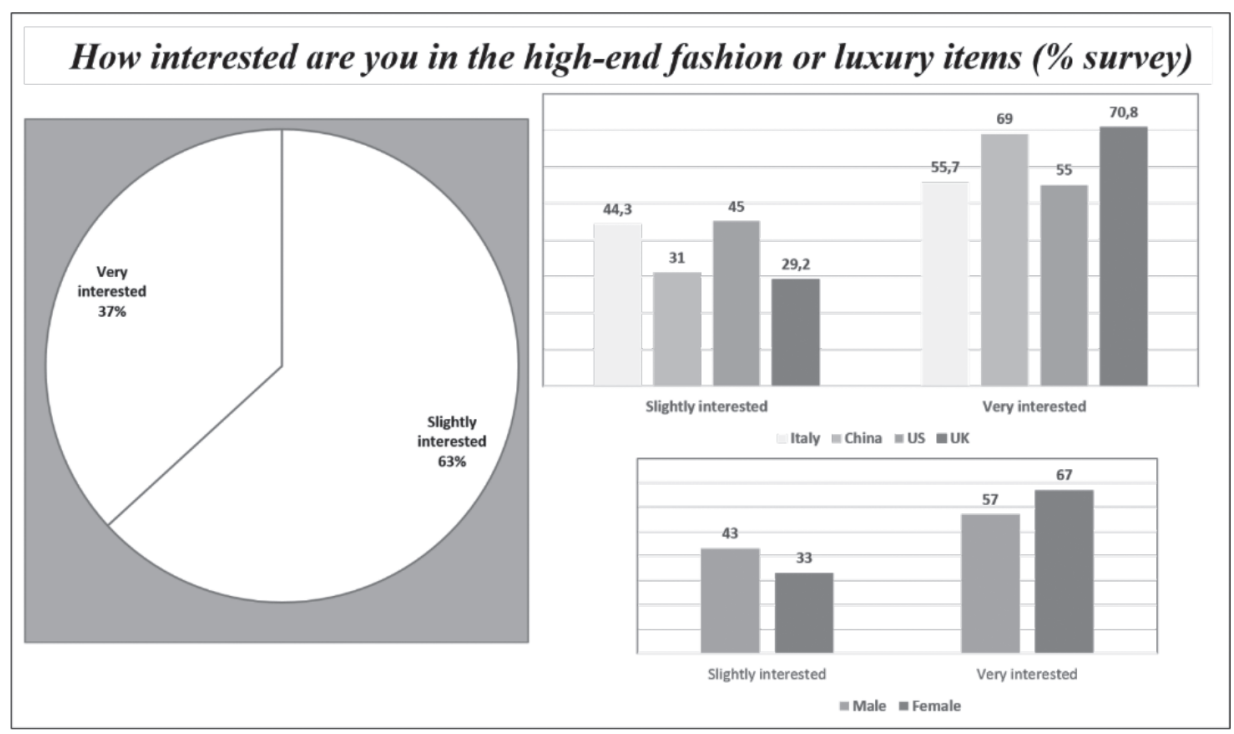

o Social media - As previously stated, the main purchasing driver of luxury brands is their power to create identity (Ellwood \& Shekar, 2008; Giovannini et al., 2015; Parment, 2012; Yarrow \& O'Donnell, 2009). Social media reinforce this function. Posting a certain image and getting "likes" is an important self-validation and confidence boost (Baron, 2015; Barton et al., 2012b). New generations feel the pressure to conform to the norms of the reference group (Yarrow \& O'Donnell, 2009). Besides, through social media platforms, such as Instagram, anonymous people can reach the same level of popularity as some celebrities (Yarrow \& O'Donnell, 2009). "Influencers" connect in a direct way with their followers as their daily lives are more comparable and easier to imitate (Giovannini et al., 2015). Everything they show becomes automatically desired and viral.

- Trading up and trading down - Consumers' priorities have changed. They spend less money on everyday commodities (trading down) and more on products, services, or experiences that provide more enjoyment (trading up) (Okonkwo, 2007). This explains the triumph of mixing and matching affordable and luxury items. Consumers may wear basics such as a T-shirt from Zara with a luxury purse (Vander, 2015). This behavior goes along with the need for conformity but with a level of differentiation.

- Quality and experiences - Millennials spend their money on products which display authenticity, originality, heritage and, even more importantly, experience (Yarrow \& O’Donnell, 2009).

- From exclusivity to accessibility - Society is "democratized". Products and brands that were previously envisaged only for wealthy people are now more accessible to the middle class (Brun \& Castellli, 2013; Silverstein \& Fiske, 2003).

o The innovations of luxury brands - Adapting to millennials' preferences has become a necessity and implies a shift in the use of marketing techniques (The Economist, 2014). A considerable amount of millennials' purchases is made online, specifically they account for 
$8 \%$ of the luxury market worldwide (D'Arpizio et al., 2016). Therefore, companies must start relying more on tools like ecommerce, mobile-commerce, or influencers in order to create engagement and offer these products and services that are attractive to this generation (Baron, 2015; Barton et al., 2012a; Boston Consulting Group, 2015; Moreno et al., 2017).

\section{METHODOLOGY}

Millennials combine exclusivity with commonality, individuality with gregarious instinct, in a way never seen before. Under these circumstances, of the two types of scarcity previously mentioned scarcity due to a time limitation and scarcity due to a quantity limitation - the latter is the one fitting better when targeting this group. An analysis of the segmentation strategy of luxury fashion brands (D'Arpizio \& Levato, 2014) allows to identify three main strategies for managing scarcity as a salient attribute in the millennial marketing: (a) offering an exclusive second line at a lower price; (b) applying the concept of "my luxury", extending the brand to exclusive but cheaper items; (c) offering an exclusive selection of cheaper products through an alternative distribution channel. The main purpose of all of these strategies is to create an impact on the millennial segment that could evolve to a long-term relationship over time. Taking into account these alternatives and, based on the previous literature review, two research questions can be proposed:

$R Q 1$. What is the effect of different scarcity strategies on millennials' perception of luxury fashion brands?

RQ2. What is the effect of different scarcity strategies on millennials' future relationship with luxury fashion brands?

Thus, the general goal of this empirical study is to analyze the role of scarcity as a luxury fashion brand strategy to push millennials through the different steps of their journey as clients.

The investigation focuses on how different scarcity strategies (second line, my luxury, and bargain) affect millennials in the luxury fashion industry. In order to attain this goal, this study manipulates three scarcity strategies and examines how they affect brand perception and future relationships with the brands. Taking into account that the product category with the best growth perspective in the luxury sector is that of bags and accessories (see Figure 5), the empirical study focuses on this category. In particular, travel items were considered as they can be used irrespectively of the users' gender.

FIGURE 5: Luxury sector and type of product

\begin{tabular}{|l|c|c|c|}
\hline \multicolumn{1}{|c|}{$\begin{array}{c}\text { Type of } \\
\text { product }\end{array}$} & $\begin{array}{c}\text { Number of } \\
\text { companies }\end{array}$ & $\begin{array}{c}\% \text { of } \\
\text { sales }\end{array}$ & $\begin{array}{c}\% \text { of } \\
\text { growth }\end{array}$ \\
\hline $\begin{array}{l}\text { Bags and } \\
\text { accessories }\end{array}$ & 10 & $7.4 \%$ & $+13.4 \%$ \\
\hline Others & 11 & $32.5 \%$ & $+10.8 \%$ \\
\hline Cosmetics & 10 & $13.9 \%$ & $+6.5 \%$ \\
\hline $\begin{array}{l}\text { Clothes and } \\
\text { shoes }\end{array}$ & 41 & $19.5 \%$ & $+4.4 \%$ \\
\hline $\begin{array}{l}\text { Watches and } \\
\text { jewelry }\end{array}$ & 28 & $26.7 \%$ & $+2 \%$ \\
\hline
\end{tabular}

Source: Deloitte (2017)

To avoid the influence of the halo effect that accompanies the attribute brand, all the items considered pertained to the same brand: Louis Vuitton. The choice of this brand can be justified from different perspectives. First, as a division of LVMH, according to Forbes (May 2017), it is the world's most valuable luxury brand (USD 28.8 billion). Secondly, it is one of the most desired fashion brands among female millennials (Ypulse, 2017). Hence, it is particularly suitable for the kind of simulation performed in this work. Moreover, Louis Vuitton is the benchmark in the market of travel products, in which it was a pioneer. Participants were given four images of luxury fashion items that are offered by Louis Vuitton. Each item was accompanied by some clues - price and distribution channel - that associated each item with a different scarcity strategy.

The images and the descriptions shown to participants in the survey are shown below (Figure 6). A control condition in the shape of 
FIGURE 6: Images of different stimuli

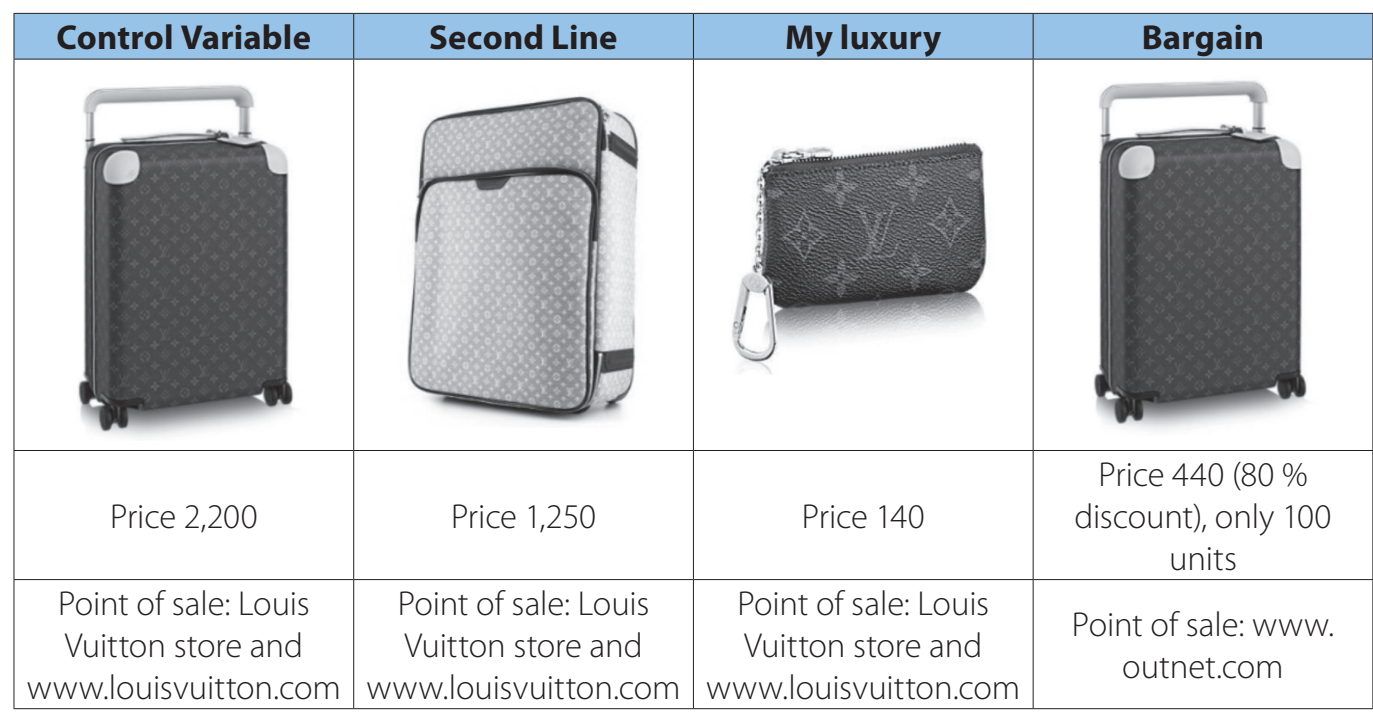

a traditional item with a regular price and regular distribution channel was included. The same stimulus of the control condition was used as an aspirational scenario to ascertain the future expected relationship of the survey participants with the brand. They were randomly assigned to three different conditions.

After being shown the pictures, participants were asked to answer different questions related to brand perception and their future relationship with the brand. The following scales were used:

o Luxury brand perception - The scale proposed by Dubois and others (2001) was used. It is an 18-item scale that includes the dimensions of distinction, elitism, and hedonism that are supposed to motivate the purchase of luxury products.

- Intention of purchase was measured by a single item scale, in accordance with the procedure commonly used in the literature (Choi \& Rifon, 2012).

- Some control variables related to fashion luxury brand behavior (Dubois et al. 2001) and demographics were included.

The characteristics of the empirical study are shown in Figure 7.
FIGURE 7: Empirical study

\begin{tabular}{|c|c|}
\hline Universe & Millennial generation \\
\hline Unit sample & $\begin{array}{l}\text { Individuals born between } 1995 \\
\text { and 2000, } \\
\text { university degree holders who } \\
\text { are employed or are undertaking } \\
\text { an internship in companies }\end{array}$ \\
\hline $\begin{array}{l}\text { Method of } \\
\text { survey }\end{array}$ & Personal interview with a Tablet. \\
\hline Survey size & $\begin{array}{l}192 \text { valid } \\
64 \text { each scenario: } \\
\text { o Second Line + My Luxury + } \\
\text { Control } \\
\text { o Second Line + Bargain + } \\
\text { Control } \\
\text { o My Luxury + Bargain + Control }\end{array}$ \\
\hline $\begin{array}{l}\text { Procedure of } \\
\text { sampling }\end{array}$ & Snowball \\
\hline $\begin{array}{l}\text { Variables } \\
\text { from the } \\
\text { questionnaire }\end{array}$ & $\begin{array}{l}\text { o Attributes of the brand LV } \\
\text { (Likert 1-7). } \\
\text { o Probability of current } \\
\text { purchase of each scenario } \\
\text { (Likert 1-7). } \\
\text { o Purchase intent in the future } \\
\text { of an LV travel suitcase (1-7). } \\
\text { o Socio-demographic } \\
\text { characteristics of respondents }\end{array}$ \\
\hline Date & April/May 2018 \\
\hline
\end{tabular}




\section{RESULTS}

After gathering the information, 192 useful responses were obtained, of which $65.3 \%$ were provided by women with a mean age of 23.5 years $(s . d=7.2)$. Figure 8 shows the results of the luxury brand perception scale regarding the brand used as a stimulus, Louis Vuitton. The mean value of all the attributes exceeds 3 on a 1 to 7 scale, with the exception of the items "Louis Vuitton shows who one is" and "Louis Vuitton makes life more beautiful". explained of $66.1 \%)$, so the final component matrix relates each of these three factors with each of the original variables. According to this matrix (see Figures 9-11), Factor 1, Factor 2, and Factor 3 are associated with hedonism, elitism, and vanity, respectively. This factor structure is coherent with the proposal of Dubois and others (2001).

FIGURE 8: Luxury brand perception

\begin{tabular}{|l|c|c|}
\hline & Mean & $\begin{array}{c}\text { Standard } \\
\text { deviation }\end{array}$ \\
\hline Do you believe that Louis Vuitton represents luxury? & 5.87 & 1.324 \\
\hline Do you consider Louis Vuitton an elitist brand? & 5.79 & 1.279 \\
\hline Do you consider Louis Vuitton a select brand? & 5.52 & 1.528 \\
\hline Do you consider Louis Vuitton an expensive brand? & 5.48 & 1.053 \\
\hline Not so many people own Louis Vuitton. & 5.44 & 1.461 \\
\hline Is Louis Vuitton a top quality brand? & 5.39 & 1.440 \\
\hline Do you consider Louis Vuitton to be for refined people? & 5.20 & 1.606 \\
\hline Do you consider Louis Vuitton to be aesthetic? & 4.88 & 1.556 \\
\hline Is Louis Vuitton not mass produced? & 4.47 & 1.652 \\
\hline Is Louis Vuitton an outstanding brand? & 4.43 & 1.700 \\
\hline Do you believe that Louis Vuitton is a brand to dream about? & 4.43 & 1.685 \\
\hline Do you consider Louis Vuitton a gratifying brand? & 4.28 & 1.718 \\
\hline Do you believe that people who own this brand have good taste? & 3.82 & 1.680 \\
\hline Owning Louis Vuitton lets me differentiate myself from others. & 3.77 & 2.167 \\
\hline Do you consider it a real pleasure to own Louis Vuitton? & 3.45 & 2.020 \\
\hline Is Louis Vuitton full of sensuality? & 3.13 & 1.701 \\
\hline Does Louis Vuitton show who one is? & 2.50 & 1.759 \\
\hline Do you believe that Louis Vuitton makes life more beautiful? & 2.27 & 1.542 \\
\hline
\end{tabular}

A factor analysis was carried on all the items of the luxury brand preference scale; however, the values of the communalities suggested the convenience of deleting the item "Louis Vuitton are not mass produced" (.493). The new factor analysis was acceptable (KMO = .894; Bartlett's test Sig. $=.00$ ) and all the items demonstrated a communality over .5. There were three factors with an eigenvalue higher than 1 (total variance
FIGURE 9: Eigenvalues

\begin{tabular}{|l|c|c|c|}
\hline \multirow{2}{*}{ Factor } & \multicolumn{3}{|c|}{$\begin{array}{c}\text { Extraction sum of squared } \\
\text { loadings }\end{array}$} \\
\cline { 2 - 4 } & Total & $\begin{array}{c}\text { \% of } \\
\text { variance }\end{array}$ & $\begin{array}{c}\text { \% } \\
\text { cumulative }\end{array}$ \\
\hline 1 & 4.452 & 27.187 & 27.187 \\
\hline 2 & 3.362 & 20.775 & 47.962 \\
\hline 3 & 2.961 & 18.151 & 66.113 \\
\hline
\end{tabular}


FIGURE 10: Structure matrix (Oblimin)

\begin{tabular}{|c|c|c|c|}
\hline & \multicolumn{3}{|c|}{ Factor } \\
\hline & 1 & 2 & 3 \\
\hline $\begin{array}{l}\text { Do you believe that Louis Vuitton } \\
\text { is a brand to dream about? }\end{array}$ & .840 & .125 & .108 \\
\hline $\begin{array}{l}\text { Do you consider Louis Vuitton to } \\
\text { be aesthetic? }\end{array}$ & .818 & .217 & .02 \\
\hline $\begin{array}{l}\text { Do you consider Louis Vuitton a } \\
\text { gratifying brand? }\end{array}$ & .796 & .046 & .15 \\
\hline $\begin{array}{l}\text { Do you believe that people who } \\
\text { own this brand have good taste? }\end{array}$ & .787 & .187 & .20 \\
\hline $\begin{array}{l}\text { consider it a real pleasure } \\
\text { Louis Vuitton? }\end{array}$ & .771 & .061 & .31 \\
\hline $\begin{array}{l}\text { Is Louis Vuitton a top quality } \\
\text { brand? }\end{array}$ & .669 & .370 & .12 \\
\hline $\begin{array}{l}\text { Is Louis Vuitton an outstanding } \\
\text { brand? }\end{array}$ & .656 & .360 & .30 \\
\hline $\begin{array}{l}\text { Do you believe that Louis Vuitton } \\
\text { makes life more beautiful? }\end{array}$ & .606 & -.021 & .42 \\
\hline Is Louis Vuitton full of sensuality? & .578 & .201 & .433 \\
\hline $\begin{array}{l}\text { onsider Louis Vuitton a } \\
\text { and? }\end{array}$ & .208 & .796 & .27 \\
\hline $\begin{array}{l}\text { Do you believe that Louis Vuitton } \\
\text { represents luxury? }\end{array}$ & .264 & .775 & \\
\hline $\begin{array}{l}\text { consider Louis Vuitton an } \\
\text { and? }\end{array}$ & .070 & .709 & .2 \\
\hline $\begin{array}{l}\text { consider Louis Vuitton an } \\
\text { ve brand? }\end{array}$ & -.029 & .667 & -.3 \\
\hline $\begin{array}{l}\text { Do you consider Louis Vuitton to } \\
\text { be for refined people? }\end{array}$ & .327 & .652 & \\
\hline $\begin{array}{l}\text { Not so many people own Louis } \\
\text { Vuitton. }\end{array}$ & .168 & .593 & \\
\hline $\begin{array}{l}\text { Does Louis Vuitton show who } \\
\text { one is? }\end{array}$ & .141 & .144 & .83 \\
\hline & .221 & .293 & \\
\hline
\end{tabular}

FIGURE 11: Transformation matrix

\begin{tabular}{|c|c|c|c|}
\hline Factor & $\mathbf{1}$ & $\mathbf{2}$ & $\mathbf{3}$ \\
\hline 1 & 1.000 & .539 & -.162 \\
\hline 2 & .539 & 1.000 & -.179 \\
\hline 3 & -.162 & -.179 & 1.000 \\
\hline
\end{tabular}

An ANOVA test was carried out to observe the differences in the factors between different scenarios. As can be seen in Figure 12, there are no statistically significant differences between shopping scenarios in Factor 1 (hedonism) and
Factor 2 (elitism). However, there are statistically significant differences in Factor 3 (vanity). These results suggest that the scarcity strategy does not affect brand equity in terms of hedonism and elitism; however, it produces an effect on the vanity associated with the brand. This result is very interesting as it shows that not all luxury brand dimensions are equally affected by the scarcity strategy. A comparison of the means of Factor 3 between scenarios shows that the pure scarce scenario (bargain treatment) is that with the lowest mean on the vanity factor, making it the worst strategy in terms of engaging this market segment. As previously stated, millennials are characterized by a low need for exclusiveness but a high need for experience and joy. In the same way, my luxury treatment also shows a very low mean of the vanity factor. It should be highlighted that the mean values are negative in both scenarios, showing that there is an inverse relationship between the value of vanity and the presence of these treatments. The best scenario in terms of vanity is the second line treatment, even more than the control scenario that corresponds to a standard Louis Vuitton item at a regular price.

FIGURE 12: ANOVA (Scarcity strategy - luxury brand perception)

\begin{tabular}{|c|c|c|c|}
\hline & & Mean & Sig. \\
\hline \multirow{5}{*}{$\begin{array}{l}\text { Factor 1: } \\
\text { Hedonism }\end{array}$} & Bargain & -.0271255 & \multirow{5}{*}{.293} \\
\hline & Second line & .2166789 & \\
\hline & My luxury & -.0925366 & \\
\hline & Control & -.04855669 & \\
\hline & Total & .0000000 & \\
\hline \multirow{5}{*}{$\begin{array}{l}\text { Factor 2: } \\
\text { Elitism }\end{array}$} & Bargain & -.1825312 & \multirow{5}{*}{.228} \\
\hline & Second line & .0893226 & \\
\hline & My luxury & -.1145223 & \\
\hline & Control & .2032152 & \\
\hline & Total & .0000000 & \\
\hline \multirow{4}{*}{$\begin{array}{l}\text { Factor 3: } \\
\text { Vanity }\end{array}$} & Bargain & -.3989556 & \multirow{4}{*}{.000} \\
\hline & Second line & .5755561 & \\
\hline & My luxury & -.1896654 & \\
\hline & Control & .0912664 & \\
\hline
\end{tabular}


The second research question related to the effect of scarcity strategies on shopping intention. Shopping intention was measured in two different timelines:

o current shopping intention, referring to the shopping intention after showing the treatment;

o future shopping intention, referring to the shopping intention of a standard luxury product at a regular price (the same that was used as the control treatment) under a hypothetical situation in which the consumer was rich and wants to buy, and is able to buy, a luxury product.

The "future shopping intention" variable aims to eliminate the income constraint that could negatively affect future probability of shopping. As expected, the mean future shopping intention - under no income constraint - is higher than the current shopping intention $(t=-11.83$, Sig. = $.00)$, see Figure 13. that the scarcity strategy of luxury brands can affect the millennials' current behavior while having no effect on their future behavior.

FIGURE 14: ANOVA (scarcity strategy - current/future shopping intention)

\begin{tabular}{|l|l|c|c|}
\hline \multicolumn{2}{|l|}{} & Mean & Sig. \\
\hline \multirow{4}{*}{$\begin{array}{l}\text { Current } \\
\text { shopping } \\
\text { intention }\end{array}$} & Bargain & 3.07 & \\
\cline { 2 - 3 } & Second line & 3.80 & \multirow{4}{*}{.000} \\
\cline { 2 - 3 } & My luxury & 2.63 & $\mathbf{4}$ \\
\cline { 2 - 3 } & Control & 2.27 & \\
\cline { 2 - 3 } & Total & 2.88 & \\
\hline \multirow{4}{*}{$\begin{array}{l}\text { Future shopping } \\
\text { intention }\end{array}$} & Bargain & 4.40 & \multirow{4}{*}{326} \\
\cline { 2 - 3 } & Second line & 4.13 & \\
\cline { 2 - 3 } & My luxury & 4.13 & \\
\cline { 2 - 3 } & Control & 4.53 & \\
\cline { 2 - 3 } & Total & 4.29 & \\
\hline
\end{tabular}

Finally, the control variables of gender and attitude towards luxury brands were considered. According to the results, there were no statisti-

FIGURE 13: T-test between current shopping intention and future shopping intention

\begin{tabular}{|l|l|c|c|c|c|}
\cline { 3 - 5 } \multicolumn{2}{c|}{} & Mean & N & $\begin{array}{c}\text { Standard } \\
\text { deviation }\end{array}$ & $\begin{array}{c}\text { Standard error } \\
\text { mean }\end{array}$ \\
\hline \multirow{2}{*}{ Pair 1 } & Current shopping intention & 2.88 & 193 & 1.797 & .130 \\
\cline { 2 - 6 } & Future shopping intention & 4.29 & 193 & 1.300 & .094 \\
\hline
\end{tabular}

\begin{tabular}{|l|c|c|c|c|c|c|}
\cline { 2 - 6 } \multicolumn{1}{c|}{} & Mean & $\begin{array}{c}\text { Standard } \\
\text { deviation }\end{array}$ & $\begin{array}{c}\text { Standard } \\
\text { error mean }\end{array}$ & t & gl & Sig. \\
\hline $\begin{array}{l}\text { Current shopping intention }- \\
\text { Future shopping intention }\end{array}$ & -1.403 & 1.638 & -1.169 & -11.83 & 190 & $\mathbf{. 0 0 0}$ \\
\hline
\end{tabular}

Figure 14 shows that there is a significant effect of the scarcity strategy on the current shopping intention but not on future shopping intention. In particular, while the mean current shopping intention is higher using the second line treatment, it is lower with my luxury treatment. However, there are no differences in the future shopping intention between scenarios. The future shopping intention refers to the intention of buying a regular Louis Vuitton luggage item at a standard price. Therefore, these results indicate cally significant differences in these results between men and women. On the other hand, an index of attitude towards luxury was computed as the average value of the three items of the scale proposed. As the items of this scale were reversed, a more positive value of this index indicates a worse attitude towards luxury brands. As can be seen in Figure 15, the average attitude is 3.2 on a 1-7 scale, with a standard deviation of 1.14 . 
FIGURE 15: ANOVA - Individuals with a negative attitude towards luxury

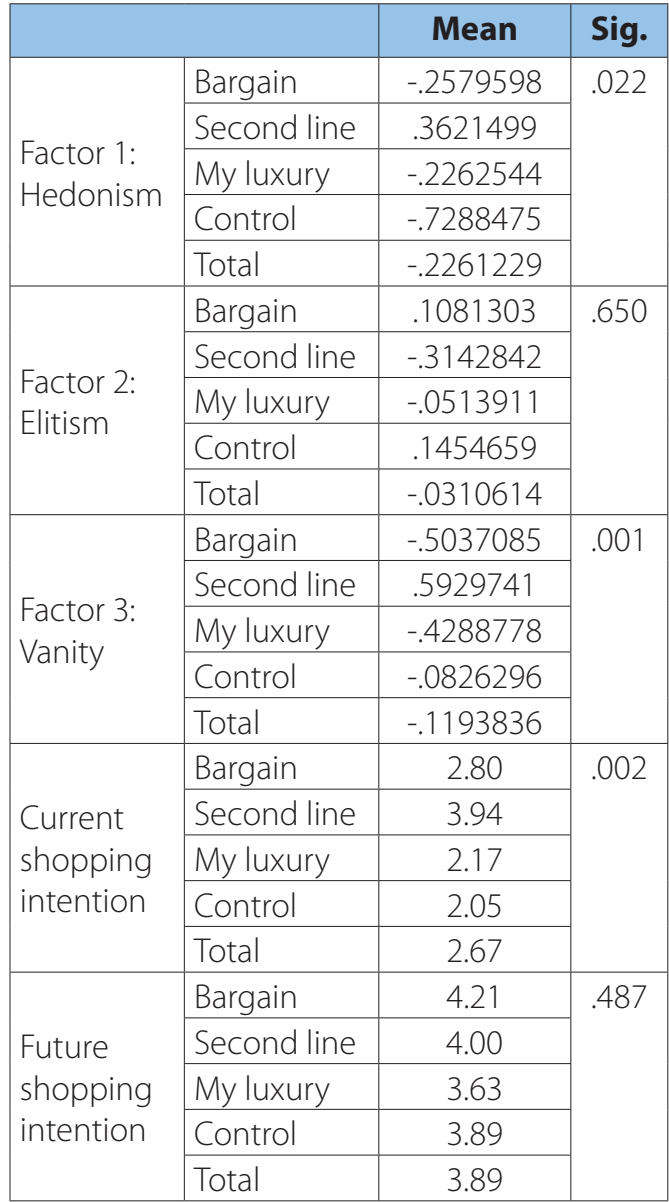

The index of attitude towards luxury was recoded in two values:

o value 1, indicating a positive attitude (lower than the average point of the scale);

o value 2, indicating a negative attitude (higher than the average point of the scale).

There are statistically significant differences in the variables analyzed between these groups. As can be seen in Figure 16, in the case of individuals with a positive attitude towards luxury, the effect of the explicative variable on luxury brand perception affects both factor 3 (vanity) and factor 2 (elitism). As in the case of vanity, the best treatment in terms of the elitism di- mension is second line. These results reinforce the appropriateness of this strategy in the segment with a positive attitude towards luxury. In this group, there is no effect of the scenario on shopping intention, neither current nor future. A possible explanation is that their positive attitude towards luxury affects behavior independently of the brand strategy. In the case of individuals with a negative attitude towards luxury (Figure 17), the most significant difference is the fact that scarcity strategy affects hedonism. Again, the best strategy is the second line.

FIGURE 16: ANOVA - Individuals with a positive attitude towards luxury

\begin{tabular}{|c|c|c|c|}
\hline & & Mean & Sig. \\
\hline \multirow{5}{*}{$\begin{array}{l}\text { Factor 1: } \\
\text { Hedonism }\end{array}$} & Bargain & .1032148 & \multirow{5}{*}{0.371} \\
\hline & Second line & .1074316 & \\
\hline & My luxury & .0014720 & \\
\hline & Control & .4009935 & \\
\hline & Total & .1480805 & \\
\hline \multirow{5}{*}{$\begin{array}{l}\text { Factor 2: } \\
\text { Elitism }\end{array}$} & Bargain & -.3110419 & \multirow{5}{*}{.019} \\
\hline & Second line & .3738873 & \\
\hline & My luxury & -.1386436 & \\
\hline & Control & .2229777 & \\
\hline & Total & .0203411 & \\
\hline \multirow{5}{*}{$\begin{array}{l}\text { Factor 3: } \\
\text { Vanity }\end{array}$} & Bargain & -.3147950 & \multirow{5}{*}{.071} \\
\hline & Second line & .4489921 & \\
\hline & My luxury & .0077164 & \\
\hline & Control & .2103329 & \\
\hline & Total & .0781804 & \\
\hline \multirow{5}{*}{$\begin{array}{l}\text { Current } \\
\text { shopping } \\
\text { intention }\end{array}$} & Bargain & 3.21 & \multirow{5}{*}{.076} \\
\hline & Second line & 3.70 & \\
\hline & My luxury & 2.92 & \\
\hline & Control & 2.41 & \\
\hline & Total & 3.02 & \\
\hline \multirow{5}{*}{$\begin{array}{l}\text { Future } \\
\text { shopping } \\
\text { intention }\end{array}$} & Bargain & 4.50 & \multirow{5}{*}{.217} \\
\hline & Second line & 4.22 & \\
\hline & My luxury & 4.45 & \\
\hline & Control & 4.96 & \\
\hline & Total & 4.54 & \\
\hline
\end{tabular}


FIGURE 17: Statistical descriptions of attitude towards luxury

\begin{tabular}{|l|c|c|c|c|c|}
\hline & N & Minimum & Maximum & Mean & $\begin{array}{c}\text { Standard } \\
\text { deviation }\end{array}$ \\
\hline Attitude towards luxury index & 193 & 1.00 & 6.00 & 3.2222 & 1.14017 \\
\hline
\end{tabular}

\section{DISCUSSION AND CONCLUSIONS}

This paper investigates the importance of managing scarcity as an attribute able to improve brand attractiveness (Aguirre, 2013). Scarcity is particularly relevant when designing an appropriate marketing mix for luxury products (Chiu \& Peng, 2018). One of the major challenges of luxury brands is the necessity for them to relate to new generations, the so-called millennials (Christen, 2018). Currently, luxury brands have started to experiment with different formulas in order to connect with this target (Cassidy, 2018). This study delves deeper into the way scarcity strategies deployed by luxury brands can affect the millennial target. To the best of our knowledge, no previous study has accomplished this sort of comparison. The experimental design of this study offers an interesting tool to describe the effect that strategies which are currently being employed have on the perception of luxury brands, and to ascertain their results in terms of future shopping intention (Christen, 2018; Oruc, 2015).

According to the literature review, three different approaches are used by luxury brands when employing scarcity as a marketing strategy (Gierl \& Huettl, 2010): (1) second line, that is, offering cheaper products but maintaining exclusivity (Zhou, Xu \& Shen, 2018); (2) my luxury, extending the luxury brands to small products (Arminen, 2017) and (3) bargain, or selling "last units" at a lower price and through an alternative distribution channel (Wu \& Lee, 2016). Through an experimental design, this study shows the effect of these strategies on luxury brand perception and on shopping intention.

In accordance with previous literature (Dubois et al., 2001), three dimensions of luxury brand perception were identified (Giovannini et al., 2015; Henninger, Tong \& Vazquez, 2018; Kaur \& Anand, 2018): hedonism, elitism and vanity. This is relevant because this study focuses on the millennials marketing while the original three-factor scale was developed for the whole market. Of the three dimensions of luxury brand perception, vanity is that which appears to be more affected by the scarcity strategy (Giovannini et al., 2015). In particular, second line is the strategy that shows a higher average value on the vanity dimension (Zhou et al., 2018).

It seems that scarcity strategy affects the current shopping intention but has no effect on the future shopping intention (Christen, 2018). Moreover, second line is the strategy that best triggers the current shopping intention. In addition, it is worth noting that the effect of each strategy is different depending on the consumer's attitude towards luxury products (Henninger et al., 2018). In the case of individuals with a positive attitude towards luxury products, all strategies seem to be equally valuable. However, a consumer with a negative attitude towards luxury products responds more favorably to the second line strategy. So, regarding the research questions of this project, the results reveal that:

(1) The best scarcity strategy in terms of improving the perception of a luxury brand among millennials is the second line. This is coherent with the notion that luxury brands should be able to develop a "millennial luxury". This refers to a concept of luxury exempt of arrogance but full of life experience (Arminen, 2017; Gierl \& Huettl, 2010; Zhou et al., 2018).

(2) The second line strategy is that which most affects millennials' intention of purchasing a luxury brand. However, there is no effect of scarcity strategies on the probability of 
buying a luxury brand in a hypothetical future scenario of no income constraints (Gierl \& Huettl, 2010).

\subsection{Managerial implications}

The results of this study have implications for targeting millennials. If a luxury brand's interest is to reinforce its character of hedonism or elitism, every mechanism can be potentially valuable (Arminen, 2017). In contrast, if the luxury brand's interest is to highlight its vanity aspect, it should take into consideration the different effects that each strategy employed can result in (Giovannini et al., 2015). The vanity dimension is connected with purchasing experience, something primarily relevant for millennials (results similar to those of Cassidy, 2018).

Therefore, these results suggest that, if the purpose is to encourage the brand's ability to provide a complete and enjoyable purchasing experience, second line should be chosen as the most appropriate strategy (Zhou et al., 2018). This version of luxury allows the millennial to access and fulfill their desire of buying these types of products, at a price level adaptable to their income constraints. This could be done by means of small personal luxury products (my luxury) or by lowering material costs (second line). The findings of this study suggest that millennials prefer entering the luxury universe naturally and that the second line strategy preserves this method of entry. Millennials renounce the opulence and arrogance of traditional luxury products and are eager to fill their lives with luxury experiences (Giovannini et al., 2015).

\subsection{Limitations and future research directions}

As with any preliminary investigation, some limitations of this project signal new research directions. Firstly, the difference in the results obtained with the variables "current shopping intention" and "future shopping intention" deserves more attention. The effects on results could be tested with different ways of measuring future shopping intention. Secondly, the online survey implies a self-selection sampling method that makes it very difficult to judge the representativeness of the sample. Thirdly, the "counterfeit" phenomenon could have an effect over the respondents' perceptions of some of the variables analyzed. Finally, the effect that each scarcity strategy has on the traditional customer base of luxury brands could be considered. The strategy that best suits millennials second line - could imply a process of brand devaluation for the traditional customer base.

\section{References}

1. Aggarwal, P., Jun, S. Y., \& Huh, J. H. (2011). Scarcity messages. Journal of Advertising, 40(3), 19-30.

2. Aguirre, A. (2013). The Effect of Consumer Persuasion Knowledge on Scarcity Appeal Persuasiveness. Journal of Advertising, 42(4), 371-379.

3. Allsop, D. T., Bassett, B. R., \& Hoskins, J. A. (2007). Word-of-mouth Research: Principles and Applications. Journal of Advertising Research, 47(4), 398-411.

4. Amaldoss, W., \& Jain, S. (2005). Pricing of Conspicuous Goods: A Competitive Analysis of Social Effects. Journal of Marketing Research, 42(1), 30-42.

5. Arminen, L. (2017). Motivational Factors Influencing Millennials to Purchase and Consume Luxury Brands: The Influence of Actual and Ideal Self-Congruity on Brand Attitude. Master's Thesis. Frankfurt: University of Frankfurt.

6. Atwal, G., \& Williams, A. (2009). Luxury Brand Marketing - The Experience is everything. Journal of Brand Management, 16(5/6), 338-346.

7. Balachander, S., \& Stock, A. (2009). Limited Edition Products: When and When not to Offer them. Marketing Science, 28(2), 336-355. 
8. Baron, K. (2015). The Secrets to Luxury Online for Millennials. Luxury Society. Sept. 16.

9. Barton, C., Fromm, J., \& Egan, C. (2012a). Millennial Passions: Food, Fashion, and Friends. New York, NY: Boston Consulting Group.

10. Barton, C., Fromm, J., \& Egan, C. (2012b). The Millennial Consumer-Debunking Stereotypes. New York, NY: Boston Consulting Group.

11. Berlyne, D. E. (1969). Arousal, Reward and Learning. Annals of the New York Academy of Sciences, 159(1), 1059-1070.

12. Blumberg, P. (1974). The Decline and fall of the Status Symbol: Some thoughts on Status in a Post-Industrial Society. Social Problems, 21(4), 480-498.

13. Boston Consulting Group (2015). The True-Luxury Global Consumer Insight. Milan: Fondazione Altagamma.

14. Brannon, L. A., \& Brock, T. C. (2001). Limiting time for responding enhances behavior corresponding to the merits of compliance appeals: Refutations of heuristic-cue theory in service and consumer settings. Journal of Consumer Psychology, 10(3), 135-146.

15. Brewer, M. B., \& Pierce, K. P. (2005). Social Identity Complexity and Outgroup Tolerance. Personality and Social Psychology Bulletin, 31(3), 428-437.

16. Brun, A., \& Castelli, C. (2013). The Nature of Luxury: A Consumer Perspective. International Journal of Retail \& Distribution Management, 41(11/12), 823-847.

17. Cassidy, N. G. (2018). The Effect of Scarcity Types on Consumer Preference in the High-end Sneaker Market. Doctoral Thesis. Boone, NY: Appalachian State University.

18. Catry, B. (2013). The Great Pretenders: The Magic of Luxury Goods. London Business School Review, 14(3), 10-17.

19. Chiu, C. H., \& Peng, Z. (2018). The optimal pricing, quantity decision, number of product of online designer with scarcity effect and product variety benefit. International Journal of Inventory Research, 5(2), 153-168.

20. Choi, S. M., \& Rifon, N. J. (2012). It is a Match: The Impact of Congruence between Celebrity Image and Consumer Ideal self on Endorsement Effectiveness. Psychology \& Marketing, 29(9), 639-650.

21. Christen, A. (2018). To what degree could Swiss Millennials' conflicting desire for fashion, brand meaningfulness and sustainability be solved by the fashion-on-demand business model. Doctoral Thesis. Genève: Haute École de Gestion de Genève.

22. Cialdini, R. B. (2009). Influence: The Psychology of Persuasion. New York, NY: Harper Collins.

23. Corneo, G., \& Jeanne, O. (1997). Conspicuous Consumption, Snobbism and Conformism. Journal of Public Economics, 66(1). 55-71.

24. D’Arpizio, C., Levato, F., Zito, D., Kamel, M. A., \& de Montgolfier, J. (2016). Luxury Goods Worldwide Market Study, Bain Report. Milan: Fondazione Altagamma.

25. Danziger, P. M. (2005). Let them Eat Cake: Marketing Luxury to the Masses-as Well as the Classes. New York, NY: Dearborn Trade Publishing.

26. D'Arpizio, C., \& Levato, F. (2014). Lens on the Worldwide Luxury Consumer. Boston, MA: Bain Company.

27. Deloitte (2017). Global Powers of Luxury Goods. The New Luxury Consumer. London: Deloitte.

28. Dubois, B., Laurent, G., \& Czellar, S. (2001). Consumer Rapport to Luxury: Analyzing Complex and Ambivalent Attitudes. Les Cahiers de Recherche, 31(1), 1-56.

29. Eagly, A. H., \& Chaiken, S. (1993). The Psychology of Attitudes. Orlando, FL: Harcourt Brace Jovanovich College Publishers.

30. Ellwood, I., \& Shekar, S. (2008). Wonder Woman: Marketing Secrets for the Trillion Dollar Customer. Berlin: Springer.

31. Fionda, A. M., \& Moore, C. M. (2009). The anatomy of the luxury fashion brand. Journal of Brand Management, 16(5/6), 347-363. 
32. Gierl, H., \& Huettl, V. (2010). Are Scarce Products always more Attractive? The Interaction of Different Types of Scarcity Signals with Products' Suitability for Conspicuous Consumption. International Journal of Research in Marketing, 27(3), 225-235.

33. Gierl, H., Plantsch, M., \& Schweidler, J. (2008). Scarcity Effects on Sales Volume in Retail. The International Review of Retail, Distribution and Consumer Research, 18(1), 45-61.

34. Giovannini, S., Xu, Y., \& Thomas, J. (2015). Luxury Fashion Consumption and Generation Y Consumers: Self, Brand Consciousness, and Consumption Motivations. Journal of Fashion Marketing and Management, 19(1), 22-40.

35. Grossman, H. I., \& Mendoza, J. (2003). Scarcity and Appropriative Competition. European Journal of Political Economy, 19(4), 747-758.

36. Henninger, C. E., Tong, Z., \& Vazquez, D. (2018). Perceived Brand Image of Luxury Fashion and Vintage Fashion - An Insight into Chinese Millennials' Attitudes and Motivations. Cham: Palgrave Macmillan.

37. Jay, E. (2012). New Breed of Consumers shakes up Luxury Fashion. Mobile Marketer, 1236.

38. Kahneman, D., Rosenfield, A. M., Gandhi, L., \& Blaser, T. (2016). Noise: How to overcome the high, hidden cost of inconsistent decision making. Harvard Business Review, 94(10), 38-46.

39. Kapferer, J. N. (2012). Abundant Rarity: The Key to Luxury Growth. Business Horizons, 55(5), 453462.

40. Kaur, H., \& Anand, S. (2018). Segmenting Generation Y using the Big Five personality traits: understanding differences in fashion consciousness, status consumption and materialism. Young Consumers, 19(4), 382-401.

41. Ko, E., Phau, I., \& Aiello, G. (2016). Luxury brand strategies and customer experiences: Contributions to theory and practice. Journal of Business Research, 69(12), 5749-5752.

42. Lascu, D. N., \& Zinkhan, G. (1999). Consumer Conformity: Review and Applications for Marketing Theory and Practice. Journal of Marketing Theory and Practice, 7(3), 1-12.

43. Lissitsa, S., \& Kol, O. (2016). Generation X vs. Generation Y. A Decade of Online Shopping. Journal of Retailing and Consumer Services, 31, 304-312.

44. Lynn, M., \& Harris, J. (1997). Individual Differences in the Pursuit of Self-uniqueness through Consumption. Journal of Applied Social Psychology, 27(21), 1861-1883.

45. Lystig F. L., \& Johnson, K. K. (2003). Personal Selling Approaches used in Television Shopping. Journal of Fashion Marketing and Management: An International Journal, 7(3), 249-258.

46. Mair, C. (2018). The Psychology of Fashion. London: Routledge.

47. Moreno, F. M., La Fuente, J. G., Carreón, F. Á., \& Moreno, S. M. (2017). The Characterization of the Millennials and Their Buying Behavior. International Journal of Marketing Studies, 9(5), 135-144.

48. Okada, E. M. (2005). Justification Effects on Consumer Choice of Hedonic and Utilitarian Goods. Journal of Marketing Research, 42(1), 43-53.

49. Okonkwo, U. (2007). Luxury Fashion Branding: Trends, Tactics, Techniques. Basingstoke: Palgrave Macmillan.

50. Oruc, R. (2015). The Effects of Product Scarcity on Consumer Behavior: A Meta-Analysis. Doctoral dissertation. Frankfurt: Europa-Universität Viadrina.

51. Parment, A. (2012). Generation Y in Consumer and Labour Markets. London: Routledge.

52. Pribram, K. H., \& McGuinness, D. (1975). Arousal, Activation, and Effort in the Control of Attention. Psychological Review, 82(2), 116-149.

53. Radón, A. (2012). Luxury brand exclusivity strategies-An illustration of a cultural collaboration. Journal of Business Administration Research, 1(1), 106-110.

54. Ressel, C. (2016). How Millennial Consumers Have Increased the Demand for Luxury Brands. Doctoral Thesis. Helsinki: Metropolia University of Applied Sciences. 
55. Shiller, R. (2015). Irrational exuberance: Revised and expanded. $3^{\text {rd }}$ ed. Princeton, NJ: Princeton University Press.

56. Silverstein, M., \& Fiske, N. (2003). Luxury for the Masses. Harvard Business Review, 81(4), 48-57.

57. Solomon, M. (2017). How Millennials Will Reshape the Luxury Market. New York, NY: Forbes.

58. Stock, A., \& Balachander, S. (2005). The Making of a Hot Product: A Signaling Explanation of Marketers' Scarcity Strategy. Management Science, 51(8), 1181-1192.

59. Suri, R., Kohli, C., \& Monroe, K. B. (2007). The Effects of Perceived Scarcity on Consumers' Processing of Price Information. Journal of the Academy of Marketing Science, 35(1), 89-100.

60. Thaler, R. H., \& Ganser, L. J. (2015). Misbehaving: The making of behavioral economics. New York, NY: Norton.

61. The Economist (2014). Marques for Millennials. Young People Choose and Buy Differently. December $11^{\text {th }}, 2014$.

62. Tian, K. T., Bearden, W. O., \& Hunter, G. L. (2001). Consumers' Need for Uniqueness: Scale Development and Validation. Journal of Consumer Research, 28(1), 50-66.

63. Valentine, D., \& Powers, T. (2013). Generation Y Values and Lifestyle Segments. Journal of Consumer Marketing, 30(7), 597-606.

64. Vander, L. A. (2015). Luxury Fashion Brand Innovators and Imitators on Social Media. Doctoral Thesis. Fort Worth, TX: Christian University.

65. Wang, Y., \& Griskevicius, V. (2013). Conspicuous consumption, relationships, and rivals: Women's luxury products as signals to other women. Journal of Consumer Research, 40(5), 834-854.

66. Whittler, T. E. (1994). Eliciting Consumer Choice Heuristics: Sales Representatives' Persuasion Strategies. Journal of Personal Selling \& Sales Management, 14(4), 41-53.

67. Worchel, S. (1992). Beyond a Commodity Theory Analysis of Censorship: When Abundance and Personalist enhance Scarcity Effects. Basic and Applied Social Psychology, 13(1), 79-92.

68. Wu, L., \& Lee, C. (2016). Limited Edition for Me and Best Seller for you: The impact of Scarcity versus Popularity Cues on Self-versus Other-purchase Behavior. Journal of Retailing, 92(4), 486-499.

69. Yarrow, K., \& O'Donnell, J. (2009). Gen Buy: How Tweens, Teens and twenty-somethings are revolutionizing Retail. New York, NY: John Wiley \& Sons.

70. Ypulse (2017). Millennials Reveal Who Represents Their Generation. New York.

71. Zhou, J., Xu, X., \& Shen, B. (2018). Selling luxury fashion to conspicuous consumers in the presence of discount sensitivity behavior. International Transactions in Operational Research, 25(8), 1763-1784.

72. Zhu, M., \& Ratner, R. K. (2015). Scarcity Polarizes Preferences: The Impact on Choice among Multiple Items in a Product Class. Journal of Marketing Research, 52(1), 13-26. 